\title{
Pengaruh Sistem Pendidikan Terhadap Perilaku Pencegahan Penyakit HIV/AIDS Pada Siswa SMP Di Surakarta
}

\author{
Ramadhaningtyas Maghfirotul Fajriani ${ }^{1}$, Hardjono $^{1}$, Sumardiyono ${ }^{1}$ \\ 1. Fakultas Kedokteran, Universitas Sebelas Maret
}

Korespondensi : ramadhaningtyas@student.uns.ac.id

\begin{abstract}
ABSTRAK
Pendahuluan: HIV/AIDS menjadi salah satu masalah utama kesehatan dan sosial karena penyebaran penyakit HIV/AIDS dipengaruhi oleh perilaku individu. Pembentukan perilaku individu dipengaruhi oleh faktor internal dan eksternal, salah satunya adalah lingkungan sekolah. Berdasarkan hasil penelitian sebelumnya ditemukan adanya sikap positif terhadap HIV/AIDS lebih banyak pada kelompok responden di pesantren, namun terbatas hanya pada sikap. Tujuan penelitian ini adalah untuk mengetahui pengaruh sistem pendidikan terhadap perilaku pencegahan penyakit HIV/AIDS pada siswa SMP yang ada di Surakarta.

Metode: Penelitian ini merupakan penelitian analitik observasional menggunakan metode potong lintang (cross sectional) dengan jumlah subjek sebanyak 100 siswa. Rincian subjek yaitu 50 siswa bersekolah dengan sistem pendidikan umum (non-boarding school) dan 50 siswa bersekolah dengan sistem pendidikan boarding school. Pengumpulan data dilakukan dengan cara pengisian kuesioner dan dianalisis menggunakan Chi-square dan diolah menggunakan penghitungan statistik

Hasil dan pembahasan: Karakteristik subjek penelitian yang diteliti adalah jenis kelamin, umur, dan pendidikan orang tua. Jumlah laki-laki lebih sedikit (48\%) dibanding jumlah perempuan (52\%). Umur ditemukan kelompok 14 tahun (68\%), 13 tahun (22\%), 15 tahun (10\%). Pendidikan orang tua ditemukan jumlah tamat perguruan tinggi lebih banyak (52\%) dibandingkan tamat SMA (48\%). Hasil penghitungan statistik menggunakan Chi-square menunjukkan sistem pendidikan bermakna secara statistik terhadap perilaku pencegahan penyakit HIV/AIDS pada siswa SMP di Surakarta dengan $p=0,009$. Hal ini bisa terjadi karena pembelajaran agama yang lebih efisien, pembatasan penggunaan telepon seluler dan akses internet, serta meminimalisir hubungan antara lawan jenis.

Kesimpulan: Terdapat pengaruh sistem pendidikan terhadap perilaku pencegahan penyakit HIV/AIDS pada siswa SMP di Surakarta.
\end{abstract}

Kata Kunci: sistem pendidikan, perilaku, HIV/AIDS, siswa SMP

\begin{abstract}
Introduction: HIV/AIDS become one of the major problems on the health and social sector because of the transmission is affected by individual's behaviour. The behaviour's conformation is influenced by internal and external factors including school's environment. According to previous studies, positive attitude towards HIV/AIDS found on the boarding school's students more. Because of the outcome of previous studies, the researcher desires to discover the influences of the educational system toward HIV/AIDS prevention behaviour of Junior High School in Surakarta.

Methods: This study was an analytic-observational study with the cross sectional analysis. Subjects were used was 100 students consist of 50 students from boarding schools and 50 students from non-boarding schools. Data collection is done by filling out questionnaire. The relationship between variables analysed by Chi-square and processed using statistical calculations.

Results and discussions: The researched subject characteristics are gender, age, and parents' education. The number of male's group (48\%) and female's group (52\%). The number of age groups is 14 years (68\%), 13 years (22\%), 15 years (10\%). Parents' education found college graduates (52\%) and senior
\end{abstract}

Correspondence: Ramadhaningtyas Maghfirotul Fajriani S.Ked, Fakultas Kedokteran Universitas Sebelas Maret, ramadhaningtyas@student.uns.ac.id

Submitted :15/2/2021 Accepted :1/3/2021

Published:31/3/2021 
high school graduates (48\%). The results of statistical calculations showing the educational system is statistically associated to HIV/AIDS prevention behaviour of junior high school students in Surakarta with $p=0,009$. It can occur due to learning religion effectively, restrictions of using cell phones and internet access, and also minimizing relationship between opposite sex.

Conclusion: There is a significant influence of educational system toward HIV/AIDS prevention behaviour of junior high school students in Surakarta.

Keywords: educational system, behaviour, HIV/AIDS, junior high school students

\section{PENDAHULUAN}

Manusia adalah kekayaan bangsa. Hal ini dibuktikan dengan peran manusia sebagai sumber daya primer yang dapat mempengaruhi tercapainya tujuan utama dari pembangunan bangsa Indonesia. Tujuan utama dari pembangunan bangsa Indonesia adalah menciptakan lingkungan yang memberikan kesempatan bagi rakyatnya untuk menikmati umur panjang, sehat, dan mampu menjalankan kehidupan yang produktif. Berdasarkan data dari Badan Pusat Statistik. Indonesia diperkirakan akan mendapat bonus demografi pada tahun 2020. Bonus demografi terjadi ketika mayoritas penduduk berada pada kelompok usia produktif yang akan menentukan peluang Indonesia untuk menjadi negara maju atau tetap menjadi negara berkembang. Tetapi tantangan yang dihadapi dalam menyambut bonus demografi ini cukuplah banyak, antara lain kematian dini akibat rokok, ibu melahirkan, permasalahan gizi, cedera, penyakit tidak menular, penyakit menular, narkoba dan HIV/AIDS ${ }^{1}$.

Human Immunodeficiency Virus (HIV) merupakan virus yang menyerang sistem imunitas. Infeksi virus ini mampu menurunkan kemampuan imunitas manusia dalam melawan benda-benda asing di dalam tubuh yang pada tahap terminal infeksinya dapat menyebabkan Acquired Immunodeficiency Syndrome (AIDS) ${ }^{2}$. HIV/AIDS menjadi salah satu masalah utama kesehatan dan sosial. Masalah sosial dapat terjadi karena penyebaran HIV/AIDS dipengaruhi oleh perilaku individu dan pengaruh dari individu satu ke individu yang lain.

Kementerian Kesehatan Republik Indonesia melaporkan pada tahun 2014 ditemukan kecenderungan terjadinya peningkatan cepat laju kasus HIV dan peningkatan lambat laju kasus AIDS dari tahun ke tahun. Berdasarkan laporan situasi perkembangan HIV/AIDS terkini yang dikeluarkan pada tahun 2017, HIV/AIDS telah menyebar di 421 (81,9\%) dari 514 kabupaten/kota yang tersebar di seluruh provinsi di Indonesia. Jumlah kasus HIV yang dilaporkan dari bulan Januari sampai dengan Desember 2017 sebanyak 48.300 orang dengan persentase kumulatif HIV tertinggi pada kelompok umur 25 - 49 tahun (69,3\%), diikuti dengan kelompok umur $20-24$ tahun $(17,1 \%), \geq 50$ tahun $(7,3 \%), 15-19$ tahun $(3,6 \%), \leq 4$ tahun $(1,9 \%)$ dan $5-14$ tahun $(0,9 \%)$. Adapun jumlah kasus AIDS yang dilaporkan dari bulan Januari sampai dengan Desember 2017 sebanyak 9.280 orang dengan persentase kumulatif AIDS tertinggi pada kelompok umur 30 - 39 tahun (35,2\%), diikuti dengan kelompok umur 20 - 29 tahun (29,5\%), $40-49$ tahun $(17,7 \%), 50-59$ tahun $(7,9 \%), \geq 60$ tahun $(2,7 \%), 15-19$ tahun $(2,3 \%), 1-4$ tahun $(1,5 \%)$ dan $5-14$ tahun $(1,2 \%)^{3}$.

Kasus HIV/AIDS lebih banyak terjadi pada kelompok usia produktif, yaitu $20-59$ tahun. Hal ini menunjukkan bahwa infeksi HIV terjadi sejak usia yang lebih muda yaitu 10 - 15 tahun karena masa inkubasi virus terjadi selama 5 - 10 tahun sejak pertama kali terjadi infeksi (2). Usia 10 - 15 tahun merupakan usia remaja awal atau dalam tingkatan pendidikan SMP. Masa pendidikan SMP merupakan masa krusial karena siswa SMP mengalami masa pubertas yaitu terjadinya transisi pertumbuhan dan perkembangan baik secara psikologis maupun fisiologis. 
Perkembangan psikologis yang terjadi pada siswa SMP memiliki sifat kritis, sensitif, dan kontrol emosi yang belum baik. Ketika terjadi interaksi timbal balik antara emosi dengan lingkungan yang kurang baik, maka siswa SMP akan terpengaruh untuk melakukan perilaku kenakalan, salah satunya adalah perilaku kenakalan yang berisiko menyebabkan HIV/AIDS ${ }^{4}$.

Perilaku yang terbentuk pada individu dipengaruhi oleh faktor internal yaitu karakteristik orang bersangkutan yang biasanya sudah terdapat sejak lahir misalnya tingkat kecerdasan, tingkat emosional, dan jenis kelamin. Selain internal, perilaku juga dipengaruhi oleh faktor eksternal yaitu lingkungan yang merupakan faktor dominan dalam menentukan perilaku seseorang misalnya lingkungan bermain, lingkungan rumah, dan lingkungan sekolah ${ }^{5}$. Lingkungan sekolah berperan penting dalam pembentukan perilaku karena sebagian besar waktu efektif yang digunakan untuk menerima informasi terjadi di sekolah ${ }^{6}$.

Pendidikan di Indonesia berbeda-beda. Terdapat pendidikan umum dan pendidikan berbasis 24 jam atau sering disebut asrama atau pesantren. Pendidikan umum mengharuskan siswa/inya untuk berada di sekolah kurang lebih selama 12 jam. Di sekolah mereka akan mempelajari ilmu eksak, pendidikan karakter dan juga pendidikan kesehatan. Tetapi tantangan yang dihadapi oleh pendidikan umum dalam mendidik karakter dan kesehatan cukuplah banyak. Pendidikan umum tidak mampu mengawasi selama 24 jam sehingga di luar jam sekolah, murid mampu bertemu lingkungan dengan pengaruh buruk seperti lingkungan bermain yang tidak tepat dan keleluasaan untuk mengakses informasi yang tidak dapat dikontrol dengan baik. Berbeda dengan pesantren yang mengawasi siswa selama 24 jam. Pesantren memiliki peraturan ketat meliputi tidak diperbolehkan pergi keluar pesantren tanpa alasan yang jelas, pembatasan penggunaan alat komunikasi dan pembatasan akses infromasi.

Sikap yang positif terhadap HIV/AIDS ditemukan lebih banyak pada kelompok responden di pesantren, dan terdapat perbedaan yang signifikan antara sikap kelompok responden di pesantren dibandingkan dengan kelompok responden di pendidikan negeri ${ }^{7}$.

Karena perbedaan sikap dari penelitian sebelumnya inilah peneliti tertarik untuk melakukan penelitian selanjutnya. Dalam penelitian ini, peneliti ingin mengetahui hubungan antara sistem pendidikan tidak hanya terhadap sikap namun pengetahuan, sikap dan tindakan yang membentuk suatu perilaku kesehatan pencegahan penyakit HIV/AIDS pada siswa SMP.

\section{METODE}

Penelitian yang dilakukan adalah penelitian analitik observasional dengan menggunakan metode potong lintang (cross-sectional). Penelitian dilaksanakan di SMP N 16 Surakarta, SMP Batik Surakarta, Pondok Pesantren Ta'mirul Islam Surakarta dan Pondok Pesantren AlMuayyad Surakarta pada bulan Mei 2019.

Populasi sasaran untuk penelitian ini adalah siswa/i SMP yang bersekolah di sekolah umum dan siswa/i SMP yang bersekolah di boarding school, dengan populasi terjangkau yaitu siswa/i SMP N 16 Surakarta, SMP Batik Surakarta, Pondok Pesantren Ta'mirul Surakarta dan Pondok Pesantren Al-Muayyad Surakarta. Pemilihan populasi terjangkau dilakukan secara random. Pengambilan subjek penelitian dilakukan secara purposive random sampling. Subjek penelitian adalah siswa/i SMP berusia 13-15 tahun pada populasi terjangkau yang memenuhi kriteria inklusi dan eksklusi.

Variabel bebas dalam penelitian ini adalah sistem pendidikan dan variabel terikat dalam penelitian ini adalah perilaku pencegahan penyakit HIV/AIDS.

Data yang diperoleh kemudian diolah menggunakan IBM SPSS Statistics versi 22.0 dan dianalisis menggunakan Uji Chi-square. 
Penelitian ini dinyatakan telah lolos etik oleh KEPK FK UMS Surakarta.

\section{HASIL DAN PEMBAHASAN}

\section{Karakteristik Sampel Penelitian}

Penelitian mengenai pengaruh sistem pendidikan terhadap perilaku pencegahan penyakit HIV/AIDS dilaksanakan pada empat sekolah menengah pertama dan pondok pesantren yang ada di Surakarta, yaitu SMP N 16, SMP Batik, Pondok Pesantren Ta'mirul Islam dan Pondok Pesantren Al-Muayyad. Sampel yang digunakan dalam penelitian ini berjumlah 25 orang pada masing - masing institusi sehingga total sampel yang didapatkan dalam penelitian ini adalah 100 orang. Sampel didapatkan menggunakan metode purposive sampling, telah memenuhi kriteria inklusi dan eksklusi.

Tabel 1. Karakteristik Subjek Penelitian Pengaruh Sistem Pendidikan terhadap Perilaku Pencegahan Penyakit HIV/AIDS pada Siswa SMP di Surakarta (N=100)

\begin{tabular}{cccc}
\hline No & \multicolumn{1}{c}{ Sampel } & $\mathrm{n}$ & $(\%)$ \\
\hline 1 & Jenis Kelamin & & \\
& Laki-laki & 48 & 48,0 \\
& Perempuan & 52 & 52,0 \\
2 & Umur & & \\
& 13 & 22 & 22,0 \\
& 14 & 68 & 68,0 \\
& 15 & 10 & 10,0 \\
3 & Pendidikan terakhir Orang Tua & & \\
& Tamat SMA & 48 & 48,0 \\
& Tamat Perguruan Tinggi & 52 & 52,0 \\
\hline
\end{tabular}

Sebanyak 48 siswa/i (48\%) berjenis kelamin laki-laki dan 52 siswa/i (52\%) berjenis kelamin perempuan. Umur siswa/i bervariasi antara 13-15 tahun dengan kelompok siswa/i berumur 14 tahun memiliki jumlah paling banyak yaitu 68 siswa/i (68\%), kelompok umur 13 tahun dengan jumlah 22 siswa/i (22\%), dan kelompok umur 15 tahun dengan jumlah 10 siswa/i (10\%). Pendidikan terakhir orang tua pada penelitian ini terdiri dari dua kelompok besar, yaitu kelompok siswa/i dengan pendidikan terakhir orang tua adalah tamat SMA sebanyak 48 siswa/i (48\%) dan tamat perguruan tinggi berjumlah $52 \mathrm{siswa} / \mathrm{i}(52 \%)$.

\section{Analisis Univariat}

Tujuan analisis univariat adalah untuk mendeskripsikan satu variabel dengan menampilkan distribusi frekuensi subjek penelitian berdasarkan variabel yang diteliti. Dalam penelitian ini didapatkan hasil penelitian berupa distribusi frekuensi subjek penelitian sistem pendidikan dan perilaku pencegahan penyakit HIV/AIDS.

Tabel 2. Distribusi Frekuensi Variabel Sistem Pendidikan dan Perilaku Pencegahan Penyakit HIV/AIDS pada siswa SMP di Surakarta. (N=100)

\begin{tabular}{ccc}
\hline Variabel & Frekuensi (n) & Persentase (\%) \\
\hline Sistem Pendidikan & & \\
Sekolah Umum & 50 & 50 \\
Boarding School & 50 & 50 \\
\hline
\end{tabular}

Perilaku Pencegahan 


\begin{tabular}{lll} 
Mencegah & 47 & 47 \\
Tidak Mencegah & 53 & 53 \\
\hline
\end{tabular}

Dari tabel 2, didapatkan pada variabel sistem pendidikan, jumlah subjek terbagi menjadi dua kelompok sama besar, yaitu kelompok sistem pendidikan sekolah umum dengan jumlah 50 siswa/i (50\%) dan kelompok sistem pendidikan boarding school dengan jumlah siswa/i sebanyak 50 (50\%). Sedangkan pada variabel perilaku pencegahan penyakit HIV/AIDS, subjek penelitian cenderung berperilaku tidak mencegah dibandingkan dengan berperilaku mencegah. Jumlah subjek yang berperilaku tidak mencegah lebih banyak yaitu sejumlah 53 siswa/i (53\%) sedangkan siswa/i yang berperilaku mencegah sebanyak 47 siswa/i (47\%).

\section{Analisis Bivariat}

Tujuan analisis ini adalah untuk mengukur dua variabel, yaitu pengaruh sistem pendidikan terhadap perilaku pencegahan penyakit HIV/AIDS pada siswa SMP di Surakarta. Penelitian ini menggunakan analisis uji chi square untuk mengetahui adanya pengaruh antara kedua variabel atau tidak.

Tabel 3. Hasil Uji Analisis Chi-Square

\begin{tabular}{lccccccc}
\hline \multirow{2}{*}{ Variabel } & \multicolumn{2}{c}{ Mencegah } & \multicolumn{2}{c}{ Tidak Mencegah } & \multicolumn{2}{c}{ Total } & \multirow{2}{*}{$p$} \\
\cline { 2 - 6 } & $\mathrm{n}$ & $\%$ & $\mathrm{n}$ & $\%$ & $\mathrm{n}$ & $\%$ & \\
\hline Sistem Pendidikan & & & & & & & \\
Sekolah Umum & 17 & 17,0 & 33 & 33,0 & 50 & 50,0 & \\
Boarding School & 30 & 30,0 & 20 & 20,0 & 50 & 50,0 & 0,009 \\
Total & 47 & 47,0 & 53 & 53,0 & 100 & 100,0 & \\
\hline
\end{tabular}

Berdasarkan hasil penelitian, siswa/i yang bersekolah dengan sistem pendidikan boarding school cenderung melaksanakan perilaku pencegahan penyakit HIV/AIDS lebih baik, dibuktikan dengan jumlah siswa/i berperilaku mencegah sebanyak 30 siswa/i (30\%) dibandingkan dengan yang tidak mencegah sebanyak 20 siswa/i (20\%). Sementara siswa yang bersekolah dengan sistem pendidikan sekolah umum cenderung masih kurang dalam melaksanakan perilaku pencegahan penyakit HIV/AIDS. Hal ini bisa dilihat dari hasil penelitian yang menunjukkan siswa berperilaku tidak mencegah lebih banyak yaitu sejumlah 33 siswa/i (33\%) dibandingkan dengan yang melaksanakan perilaku pencegahan yaitu sebanyak 17 siswa/i $(17 \%)$.

Berdasarkan hasil uji chi square, didapatkan bahwa sistem pendidikan memiliki pengaruh yang signifikan terhadap perilaku pencegahan penyakit HIV/AIDS dan bermakna secara statistik karena memiliki nilai $\mathrm{p}<0,05(\mathrm{p}=0,009)$.

\section{Sistem Pendidikan dengan Perilaku Pencegahan Penyakit HIV/AIDS Siswa SMP di Surakarta}

Analisis univariat digunakan untuk mengetahui distribusi frekuensi perilaku pencegahan penyakit HIV/AIDS pada siswa/i SMP di Surakarta. Berdasarkan tabel 2, didapatkan bahwa, perilaku tidak mencegah penyakit HIV/AIDS ditemukan lebih banyak sejumlah 53\% dibandingkan dengan perilaku mencegah sebanyak $47 \%$. Hal ini bisa disebabkan oleh berbagai macam faktor, salah satunya adalah tingkat pengetahuan, sikap maupun tindakan yang masih kurang. Hal ini sesuai dengan penelitian sebelumnya yang juga mendukung hasil bahwa, pengetahuan HIV/AIDS dengan kategori baik ditemukan pada remaja dengan pendidikan di atas 
SMP sebesar 58,6\% lebih tinggi dibandingkan remaja dengan pendidikan masih SMP atau di bawah SMP $^{8}$.

Masih minimnya informasi mengenai HIV dan AIDS yang diperoleh menjadi salah satu faktor kurangnya pengetahuan dan sikap yang berdampak pada perilaku pencegahan penyakit HIV/AIDS yang buruk. Hal ini sejalan dengan penelitian sebelumnya yang menyimpulkan adanya pengaruh positif pendidikan kesehatan terhadap meningkatnya perilaku pencegahan penyakit HIV/AIDS ${ }^{9}$. Pendidikan kesehatan telah menjadi suatu langkah penting dalam pencegahan penyakit HIV/AIDS. Kementerian Kesehatan Republik Indonesia telah mengeluarkan sebuah media pembelajaran pendidikan kesehatan terkait HIV/AIDS yaitu media KIE ABAT (Aku Bangga Aku Tahu). Media KIE ABAT adalah alat untuk meratakan pengetahuan yang benar dan komprehensif tentang HIV dan AIDS kepada kaum muda populasi umum usia 13-24 tahun. Tapi penggunaan media KIE ABAT ini di dalam masing-masing sekolah masih minim, bahkan terdapat beberapa sekolah yang belum mengetahui keberadaan media KIE ABAT.

Analisis bivariat digunakan untuk mengetahui pengaruh sistem pendidikan terhadap perilaku pencegahan penyakit HIV/AIDS pada siswa SMP di Surakarta. Berdasarkan hasil tabel 4 didapatkan bahwa sistem pendidikan memiliki pengaruh yang signifikan terhadap perilaku pencegahan penyakit HIV/AIDS dan bermakna secara statistik dengan nilai $(\mathrm{p}=0,009)$. Hal ini sesuai dengan teori perilaku kesehatan yang dinyatakan oleh Connor dan Norman (2015) yaitu nilai budaya, faktor emosional, pengaruh teman sebaya termasuk yang berada di lingkungan sekolah juga memberikan pengaruh yang signifikan pada perilaku kesehatan ${ }^{10}$. Selain Connor dan Norman (2015), Notoatmodjo (2012) juga menyebutkan hal yang sama bahwa perilaku juga dipengaruhi oleh faktor eksternal yaitu lingkungan yang merupakan faktor dominan dalam menentukan perilaku seseorang misalnya lingkungan bermain, lingkungan rumah dan lingkungan sekolah ${ }^{5}$. Hasil ini selaras juga dengan teori yang dikemukakan oleh Mahat dan Scoloveno (2010) yaitu lingkungan sekolah berperan penting dalam pembentukan perilaku karena sebagian besar waktu efektif yang digunakan untuk menerima informasi terjadi di sekolah $^{6}$.

Hasil penelitian memberikan informasi bahwa siswa/i berperilaku mencegah lebih banyak ditemukan pada sistem pendidikan boarding school. Siswa/i dengan sistem pendidikan boarding school yang memiliki perilaku pencegahan HIV/AIDS berjumlah $30 \%$ sedangkan siswa/i dengan sistem pendidikan sekolah umum yang berperilaku mencegah hanya berjumlah $17 \%$. Hal ini bisa terjadi karena pada pendidikan boarding school, siswa/i mendapatkan pelajaran dan ilmu agama lebih terfokus sehingga memiliki tingkat religiusitas yang lebih tinggi dibandingkan dengan siswa/i yang bersekolah pada pendidikan umum. Hasil ini sesuai dengan penelitian yang berjudul Pengaruh Islam terhadap Pencegahan AIDS pada Mahasiswa Senegalese. Pada penelitiannya disebutkan bahwa, tingkat reilgiusitas berbanding lurus dengan perilaku pencegahan HIV/AIDS ${ }^{11}$. Hal ini disebabkan karena pendidikan agama Islam melarang perilaku seks bebas, sehingga dapat mengurangi resiko tertular HIV/AIDS.

Selain tingkat religiusitas yang tinggi, siswa/i yang bersekolah di boarding school memiliki keterbatasan dalam penggunaan telepon seluler dan akses internet. Karena keterbatasan ini, siswa/i yang bersekolah di boarding school cenderung dapat mencegah dirinya dalam mencari situs seks dan asosiasinya terhadap perilaku seks yang menyebabkan infeksi menular seksual. Hal ini sesuai dengan penelitian tentang Penggunaan Telepon Seluler dan Internet untuk Pencarian Situs Seksual dan Asosiasinya dengan Infeksi Menular Seksual. Pada penelitian tersebut menyebutkan bahwa terdapat $23 \%$ orang yang mengalami infeksi menular 
seksual dan 95\% dari penderita tersebut aktif menggunakan telepon seluler untuk mencari situs seks online ${ }^{12}$.

Selain pembatasan dalam penggunaan telepon seluler, pondok pesantren juga menerapkan aturan untuk meminimalisir hubungan antar lawan jenis. Santri pada pondok pesantren tinggal dalam pondok atau asrama yang terpisah antara laki-laki dan perempuan. Sistem belajar mengajar juga dilakukan pada tempat yang terpisah antara laki-laki dan perempuan. Seluruh kegiatan yang ada di pondok pesantren diawasi oleh guru-guru dan penjaga, sehingga terbentuk perilaku dan kebiasaan santri yang tidak bertentangan dengan norma, serta terhindar dari perilaku seks bebas yang menjadi faktor risiko tertular HIV dan AIDS. Hal ini sesuai dengan penelitian yang Pembatas Budaya dan Agama pada Edukasi Hubungan Seksual di Negara Muslim: Studi Kasus di Brunei Darussalam ${ }^{13}$.

Pada penelitian ini terdapat keterbatasan yaitu daerah yang diteliti masih dalam kota Surakarta, sehingga belum bisa diterapkan secara nasional. Untuk penelitian selanjutnya, sebaiknya penelitian tidak terbatas hanya dalam satu kota. Populasi penelitian diperluas seperti antar provinsi, sehingga hasil penelitian selanjutnya mampu diterapkan secara nasional

\section{KESIMPULAN}

Terdapat pengaruh sistem pendidikan terhadap perilaku pencegahan penyakit HIV/AIDS pada siswa SMP di Surakarta $(\mathrm{p}=0,009)$. Perilaku pencegahan penyakit HIV/AIDS lebih banyak ditemukan pada sistem pendidikan boarding school dibandingkan dengan sistem pendidikan sekolah umum.

\section{UCAPAN TERIMA KASIH}

Ucapan terima kasih disampaikan kepada Kepala Sekolah, Guru pembimbing dan muridmurid dari SMP 16 Surakarta, SMP Batik Surakarta, Pondok Pesantren Al-Muayyad Surakarta dan Pondok Pesantren serta semua pihak yang telah banyak memberikan bantuan dalam penyelesaian penelitian ini.

\section{DAFTAR PUSTAKA}

1. Kementerian Kesehatan Republik Indonesia. Buku Petunjuk Penggunaan Media KIE: ABAT (Aku Bangga Aku Tahu) Versi Pelajar. Jakarta: Pusat Promosi Kesehatan Kementerian Kesehatan Republik Indonesia; 2012

2. WHO. HIV/AIDS [Internet]. WHO. 2017 [sitas 7 April 2018]. Diunggah dari: http://www.who.int/features/qa/71/en/

3. Kementerian Kesehatan Republik Indonesia. Laporan Perkembangan HIV-AIDS dan Infeksi Menular Seksual (IMS) Triwulan IV Tahun 2017 [Internet]. AIDS Indonesia. 2017 [sitasi 7 April 2018]. Diunggah dari: http://www.aidsindonesia.or.id/ck_uploads/files/Laporan\%20HIV\%20AIDS\%20TW\%201\%2020 17.pdf

4. Wendari WN, Badrujaman A, Sismiati AS. Profil Permasalahan Siswa Sekolah Menengah Pertama (SMP) di Kota Bogor. Insight: Jurnal Bimbingan Konseling. 2016; 5(1):134-139

5. Notoatmodjo S. Metodologi Penelitian Kesehatan. Jakarta: Rineka Cipta; 2012

6. Mahat G, Scoloveno MA. HIV Peer Education: Relationship between Adolescents HIV/AIDS Knowledge and Self Efficacy. HIV/AIDS and Social Services. 2010; 9(4):371-388

7. Astuti M, Harni E. Perbedaan Sikap Terkait Pencegahan HIV/AIDS pada Siswa SMP di Pesantren dengan Sekolah Negeri di Kota Bogor. Jurnal Kebidanan. 2017; 3(3):165-170

8. Sudikno, Simanungkalit B, Siswanto. Pengetahuan HIV dan Aids pada Remaja di Indonesia. Jurnal Kesehatan Reproduksi. 2011; 1(3):145-154. 
9. Hardiningsih. Pengaruh Pendidikan Kesehatan terhadap Pengetahuan dan Sikap dalam Rangka Pencegahan Human Immunodeficiency Syndrome (HIV/AIDS) pada Siswa Kelas XI Sekolah Menengah Atas Negeri 4 Surakarta [Skripsi]. Surakarta: Universitas Sebelas Maret; 2011.

10. Conner M, Norman P. Health Behaviour: Current Issues and Challenges. Psychology and Health. 2017; 23(8):895-906.

11. Gilbert SS. The Influence of Islam on AIDS Prevention among Senegalese University Students. AIDS Education and Prevention. 2008; 20(5):399-407.

12. Jacob EA, Gordon M, Matthew JM, Jeremy H, Jeffrey HH. Mobile Phone and Internet Use Mostly for Sex-Seeking and Associations with Sexually Transmitted Infections and Sample Characteristics among Black/African American and Hispanic/Latino Men who Have Sex with Men in Three U.S. Cities. HHS Public Access Sex Transmitted Disease. 2017; 44(5):284-289

13. Tahamit NH. Cultural and Religious Barriers to Setting up Sex and Relationship Education in A Muslim Country: A Case Study of Brunei Darussalam [Thesis]. Brunei Darussalam: Univeristy of Leeds; 2015 